\title{
FASHION PEDAGOGY IN INDIA: THE LINKAGE BETWEEN FORMAL AND INFORMAL PEDAGOGY
}

\author{
Reetu Singh \\ Department of Fashion Technology \\ Axis Colleges, Kanpur, Uttar Pradesh, India
}

\begin{abstract}
The purpose of this study is to explore how "Fashion Professional's capabilities and creative skills are developed and the development of one's skills as a creative profession includes the crux process of designing which gives rise to fashion industries".

The research briefs about 'fashion pedagogy ecosphere' that has transpired from the bond between fashion pedagogy and professional development, which uplifts the industry through the amplified creative skills of the designers which defines the competencies with respect to growth.
\end{abstract}

This is in the reference of "Fashion education and Fashion industry development" based on based on the professional development of individuals via direct or indirect aspects of education. This article discusses the proficiency, dexterity and adroitness of fashion designers developed within Indian scenario.

Keywords - Skills, Development, Pedagogy, Proficiency, Dexterity

\section{INTRODUCTION}

Indian Fashion Scenario is known for its cultural heritage, elegance and colorfulness that bring out the subtlety and beauty which has sustained through innumerable decades. From 1990s to till now, the Indian fashion industry has grown by leaps and bounds with Indian fashion designer grabbing the spotlight at international events.

With the advent of globalization, numerous changes in the form of development have taken place in the Indian Fashion industry. Since education has indirect correlation with the social economy, fashion education, inherited the characteristics of traditional education, becomes as important part of fashion industrial chain by breaking through the traditional limitations and making.

This multidisciplinary approach to design education, training, and practice leads to economic development within the country.

\section{The Relevance Of FASHION EduCATION AND FASHION INDUSTRY DEVELOPMENT:}

The current fashion education system in India lies in ascertaining that it is able to meet industry requirements. Fashion institutes in India have played an integral role in nurturing the home-turf talent and providing them with resources that have helped them get a foothold in the immensely competitive business.

\section{FORMAL \& INFORMAL FASHION EDUCATION}

Fashion education has organized under two sections separately of Formal education and Informal education. Formal and informal education circumscribes swotting in an organized manner via institutions and colleges.

Formal way of educating one can be classifies as, if an individual is associated with properly scheduled classes and skill development activities to enhance their creative way of thinking amongst their field which leads them to give fruitful results. Informal education can be categorized as if a person is continuously working in any industry generally acquire more work experience, knowledge to solve problem occurred. These skilled and trained individuals accomplish targers on the basis of their capabilities of team management, communication skills, organizing, planning and presentation etc.

The participation of private sector comes through opening new universities and additional colleges and opening study centers in the existing institutions and sometimes through sponsoring courses resulted in increasing the Gross Enrolment Ratio of fashion education in the country. Private colleges are offering courses such as fashion design, textile apparel, visual merchandising, fashion communication and styling, fashion technology, industrial design and product design, fashion and lifestyle business, luxury brands, fashion media and entertainment and so on. 


\section{International Journal of Engineering Applied Sciences and Technology, 2021 \\ Vol. 5, Issue 11, ISSN No. 2455-2143, Pages 178-180 \\ Published Online March 2021 in IJEAST (http://www.ijeast.com)}

Fashion aspirant must learn and keep practicing the new technologies required in their field. So that the individual must acquire skills and must be capable of giving desired solutions for the specific problems. These qualities of coordination, communication, creativity, can be easily identified in an aspirant who has had formal education in fashion.

\section{AICTE IS CONTRIBUTING IN FASHION EDUCATION IN PERSPECTIVE OF INDUSTRIAL DEVELOPMENT IN INDIA:}

In India, government, semi government organizations provide training and skill development programs to promote and develop design excellence and entrepreneur (startup) skills. Private sector has opened up new routes of collaboration with fashion education and industries in India. The private sector has helped in modernizing of education and rebuilding facilities. Education platforms enhance the skills of an aspirant as industry needs an eclectic combination of the soft skills that are relevant.

India Design Council is an autonomous body of Government of India is spearheading the national design direction and is working with other government agencies, the design community, industry and education institutions to promote design in business, society and public services and developing design excellence.

Indian Government MINISTRY OF MICRO, SMALL AND MEDIUM ENTERPRISES (MSME) provides training and skill development programs, collaborated with private and Govt. Colleges. The assistance is provided to National level training institutions operating under the Ministry of MSME, namely, NIMSME, KVIC, Coir Board, Tool Rooms, NSIC \& MGIRI in the form of capital grant for the purpose of creation and strengthening of infrastructure and support for entrepreneurship development and skills.

\section{MOdERnization Of FASHiOn EdUCATION With FASHION INDUSTRIES: ERA OF FUSION}

Fashion industries and Fashion education are interconnected with individual's skills, innovation, creativity, research \& development, organizing data etc. which seems to be the backbone of our country's economy.

Forward thinking and innovations are the keywords which lead to the economic development within the country. Modernization occurred by providing knowledge of latest technology and methods to make individual work professionally with training sessions and camps.

Indian fashion art is an amalgamation of multiplicity of interests, originated from cultural \& social heritages which tend to contemporary era. There is vast scope for people who are practicing crafts, for textiles aspirants and for them who promote \& work for traditional elements of fashion like Chicken, Zardosi, Kanjivaram, Jamdani, Baluchari, Banarsi etc.

In today's era, power looms were overcoming the handlooms gradually as it saves time and labour charges. Demerit was that our traditional heritage of weaving manually was diminishing. To prevent this traditional art, Modi govt. has planned to make Varanasi as the hub of handloom products. To accomplish this purpose, govt. and the private organizations are working to train the workers. This is a kind of indirect education which anyone can acquire to be a part of professional world.

This is the era of brands, growing industries and e-commerce which acts as the backbone for the economy. There are so many brands national as well as international like Louis Phillipe, Allen Solly, Raymond etc. who have marked their stamp amongst people with e-platforms.

The enthralling world of fashion design has caught the fancy of generations of fashion enthusiasts and continues to inspire a number of aspiring designers to take the plunge into the fashion industry.

\section{CONCLUSION}

Many private institutions as standalone institutions have also been established in some states of India. Many private colleges command great academic prestige and social recognition. Their names carry value. They are spread over in every part of the country and offer a variety of traditional and contemporary courses of study.

\section{REFERENCE}

[1] Gopura, Sumith, 2018, "Fashion education in Sri Lanka: the nexus between formal and informal education", Pages 23-34.

[2] Keswani Avi , 2020, "How Global Fashion Design Schools Are Changing The Indian Landscapes?".

[3] Bhattacharjee Satabdi, 2018, "Evolution of Fashion Industry in India".

[4] Pilz Matthias and Regel Julia, 2019, "International Journal of Training Research" 17(4):1-17, DOI:10.1080/14480220.2019.1624350.

[5] Rahman Osmad, X Zhu,Wing-sun Liu, 2007, “An exploratory study of fashion design: designer, product and consumer

[6] Jaiswal Gitanjali, 2017," The research and development for bright future of fashion design in India: an overview", Pages-107-113

[7] Singh Rajveer, Jul 2017, "Future of textile msmes- B2C exports, article.

[8] Shamika Ravi and M. West Darrell, 2016," Building a Design Economy in India", pdf. 
[9] Biswas Asit and Hartlye Kris, March 30, 2015 "India and the Culture of Innovation," The Diplomat.

[10] Strategic Direction, "India Emerging as Innovation Hub," Volume 29, 2013, p. 26

[11] Kozlowski Anika,2016 "Innovation for a Sustainable Fashion Industry: A Design Focused Approach Toward the Development of New Business Models", DOI:10.1007/978-981-10-0245-8_5

[12] 2012,"'Innovation intelligence and entrepreneurship in the fashion industry", doi.org/10.1016/j.sbspro.2012.04.036 